\title{
EDUCOM.TV: CURSO ON LINE PARA A REDE PÚBLICA
}

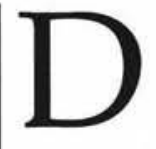

urante sete meses, de junho a dezembrode 2002, um grupo de 1.024 escolas da rede pública de educação do Estado de São Paulo vivenciou uma experiência inédita: mais de 2.250 educadores vinculados a estas escolas participaram do primeiro Curso de Aperfeiçoamento on line oferecido pela Universidade de São Paulo. O tema central do curso foi a Linguagem audiovisual na escola - uma ação educomunicativa, ou, simplesmente, Educom.TV.

Um fato inédito chamou a atenção dos observadores: $95 \%$ dos inscritos se mantiveram até o final do curso. Pela literatura existente, a média internacional de fidelidade e permanência para cursos dessa natureza é de, no máximo, $30 \%$ dos inscritos. Pelas avaliações, os professores acreditam que o curso atendeu às expectativas da rede pública de educação: "Foi realmente demais, porque sempre reclamamos que não temos chance de nos reciclar, de nos atualizar, pois aí está, algo que foi além. Pena que outros colegas não puderam estar neste curso, mas certamente trataremos de ser os difusores mais dinâmicos possíveis. Já temos embasamento para tornar nossas aulas muito mais interessantes e atuais", escreveu Teruko Navarro Moreno, uma das cursistas, em mensagem a seu tutor, no dia 22/09/02.

O curso Educom.TV, com 180 horas de duração, foi oferecido à rede pela Gerência de Informática Pedagógica/CENP da Secretaria de Estado de Educação do Estado de São Paulo, tendo sido planejado e administrado pelo NCE - Núcleo de Comunicação e Educação do Departamento de Comunicações e Artes da Escola de Comunicação e Artes da Universidade de São Paulo. Seu objetivo foi levar os cursistas a compreenderem o conceito de educomunicação e de suas práticas, a partir da análise da produção e uso da linguagem audiovisual em sala de aula. Nesse sentido, o curso promoveu um diálogo constante entre os professores-cursistas e a equipe do NCE, através da participação de quatro doutores (Ismar de Oliveira Soares, Supervisor-Geral, Adílson Citelli, Maria Cristina Costa e Marília Franco, 
orientadores educomunicacionais), 35 tutores (alunos de pós-graduação da ECA e de outras instituições universitárias da cidade de São Paulo), contando com o concurso de uma equipe operacional composta por sete estudantes de graduação, coordenados por Eliany Salvatierra.

\section{EDUCOMUNICAÇÃO VIA INTERNET}

O Educom.TV foi desenvolvido na modalidade de ensino a distância com atividades presenciais. A modalidade a distância foi garantida pela visita dos cursistas ao site do projeto, através do qual interagiam com seus tutores, dedicando, individualmente, um mínimo de oito horas semanais para o projeto, cumprindo uma rotina de discussão no fórum e de elaboração de exercícios, definidas no cronograma de cada tópico. A parte presencial do curso foi constituída por seminários e oficinas de capacitação, com duração de cinco dias, desenvolvidos ao longo do curso, na cidade de Águas de Lindóia, durante os meses de agosto e setembro. Devido ao grande número de participantes, foram promovidos quatro grandes encontros com 600 pessoas cada um.

Para a Profa.Tânia Marize Polo Bergamine, o Encontro Presencial do qual tomou parte trouxe muitas novidades e aumentou sua confiança nas possibilidades e vantagens de projetos no campo da inter-relação entre comunicação e educação: "Conhecer gente nova, idéias novas, isto nos revigora, nos faz ver como é importante a comunicação em todos os sentidos. Mais do que nunca, tenho a certeza de que a escola, principalmente a pública, é um lugar muito apropriado para se iniciar e se estimular uma educação para os meios".

A partir de outubro de 2002, 35 das escolas participantes puderam inscrever grupos de estudantes num dos produtos do Educom.TV, o projeto Tôdeolho.TV, destinado a integrar alunos da rede pública na discussão sobre a presença da televisão em suas vidas.

Ao final do curso, os professorescursistas - trabalhando em duplas, por escola inscrita - elaboraram mais de mil projetos de educomunicação a serem implementados em seus respectivos espaços educativos.

Com o Educom.TV, o NCE-ECA/USP dá início a uma modalidade avançada de formação continuada de docentes das redes públicas de educação de todo o país, tomando-se como ponto de partida a especificidade da linguagem audiovisual. Desta forma, o Comunicação e Educação da ECA dá um passo significativo no sentido de devolver à sociedade os resultados de suas pesquisas no campo da educomunicação. O NCE tem condições de atender outras Secretarias de Educação de municípios ou estados, assim como a redes de escolas particulares interessados em tomar parte em experiência semelhante de capacitação. Os contatos podem ser feitos diretamente com a coordenação do NCEECA/USP, pelo telefone (011) 30914784 , ou pelo e-mail educom tv@yahoo.com.br. 
Resumo. O conceito e as práticas de educomunicação estão sendo utilizadas em curso a distância de reciclagem de professores da rede pública estadual de ensino em São Paulo. A comunicação/educação é um campo de atividade que prepara os educadores para utilizarem as tecnologias e as linguagens dos meios de comunicação em projetos educativos. Neste curso, tratou-se da televisão e de como ela pode ser usada criticamente em sala de aula com os alunos.

Palavras-chave. educomunicação, televisão, ensino a distância, professor, escola
(Educom.TV: an online course for public schools)

Abstract. The educommunication concept and practices are being used in a distance learning course aiming at recycling state school teachers in São Paulo. Communication/education is a field of activity that prepares educators to use media technologies and languages in educational projects. In this course, television was dealt with, demonstrating how it can be used in the classroom with the students in a critical manner.

Key words: educommunication, television, distance learning, teacher, school 